\title{
BIOACTIVE MARINE-DERIVED COMPOUNDS AS POTENTIAL ANTICANCER CANDIDATES
}

\author{
MONA S ELLITHEY ${ }^{1,2}$, HANAA H AHMED ${ }^{1,2 *}$ \\ ${ }^{1}$ Department of Hormones, Medical Research Division, National Research Centre, Giza, Egypt. ${ }^{2}$ Stem Cell Lab, Center of Excellence for \\ Advanced Sciences, National Research Centre, Giza, Egypt. Email: hanaaomr@yahoo.com
}

Received: 06 August 2018, Revised and Accepted: 24 September 2018

ABSTRACT

Objective: The objective of this research was to evaluate for the $1^{\text {st }}$ time the anticancer activities of sarcophytol $\mathrm{M}$ (1), alismol (2), alismoxide (5), 7ß-acetoxy-24-methylcholesta-5-24 (28)-diene-3,19-diol (7), erythro-N-dodecanoyl-docosasphinga-(4E,8E)-dienine (8), and 24

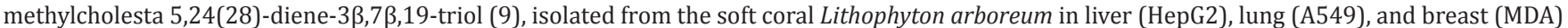
cancer cell line.

Methods: Anticancer activities of the compounds were tested using (XTT) 2,3-bis-(2-methoxy-4-nitro-5-sulfophenyl)-2H-tetrazolium-5-carboxanilide, $\mathrm{Na} 2$ ) in vitro assay in order to estimate the cytotoxicity and to determine the IC50s. The free radical scavenging activity of the compounds were measured by 1,1-diphenyl-2-picryl-hydrazil (DPPH•). All compounds were screened at $100 \mu \mathrm{g} / \mathrm{ml}$ while the most potent active compounds were assayed at lower concentrations.

Results: Compounds (7) and (9) showed a strong cytotoxic effect with $\mathrm{IC}_{50}$ of 6.07, $8.5 \mu \mathrm{g} / \mathrm{ml}$ in HepG2, 6.3, 5.5 $\mu \mathrm{g} / \mathrm{ml}$ in MDA cells, and 5.2, 9.3 $\mu \mathrm{g} / \mathrm{ml}$ in A549 cancer cell lines, respectively. In addition, moderate cytotoxicity was shown by compound (2) (IC ${ }_{50} 16.5,15$, and $\left.13 \mu \mathrm{g} / \mathrm{mL}\right)$ in $\mathrm{HepG} 2, \mathrm{MDA}$, and A549 cancer cell lines, respectively.

Conclusion: The results obtained in this research work indicated a promising potential cytotoxicity of compounds (7) and (9) compared to its safety margins in Vero cells, and the expected cytostatic effect of compound (2) can be used in drug cocktails for the treatment of the major cancer types' lung, breast, and liver cancer.

Keywords: Soft corals, Steroids, Anticancer, HepG2, MDA, A549.

(C) 2018 The Authors. Published by Innovare Academic Sciences Pvt Ltd. This is an open access article under the CC BY license (http://creativecommons. org/licenses/by/4. 0/) DOI: http://dx.doi.org/10.22159/ajpcr.2018.v11i11.28954

\section{INTRODUCTION}

Natural products derived from marine organisms have been identified as promising sources of anticancer drug candidates in pharmaceutical industries. Steroids are considered as major natural compounds in soft corals [1]. A multitude of studies mentioned a wide range of pharmacological activity for these compounds such as anti-inflammatory [2], antifouling [3], and anticancer [2,4,5]. In our previous work, the soft coral Litophyton arboreum total extract has been found to show promising anticancer activity in the ovarian (Hela) and leukemia (U937) cell lines, these findings supported the isolation, and the purification of the most active compounds that showed promising cytotoxic activity and high safety margins reported in our previous study [6]. To continue our line of research on the anticancer activities potentially these compounds, we assess for the $1^{\text {st }}$ time, the anticancer activities of these compounds in liver (HepG2), breast (MDA), and lung (A549) cancer cell lines.

\section{METHODS}

\section{Marine-derived compounds}

Nine compounds, sarcophytol M (1), alismol (2), alismoxide (5), $7 \beta$-acetoxy-24-methylcholesta-5-24(28)-diene-3,19-diol(7), erythro-Ndodecanoyl-docosasphinga-(4E,8E)-dienine(8), and 24-methylcholesta5,24 (28)-diene-3 $\beta, 7 \beta, 19$-triol (9) were isolated and identified from the soft coral L. arboreum in our previous study [6] as shown in Fig. 1.

Only six of the compounds $(1,2,5,7,8$, and 9) were subjected to this evaluation due to their availability.

\section{Cell culture}

All the cell lines were obtained from VACSERA (the holding company for biological products and vaccines). Media were purchased from Lonza
Verviers SPRL, Belgium. Trypsin-EDTA, fetal bovine serum (FBS), and antibiotics (penicillin, streptomycin, and fungizone) were acquired from SeraLab, UK.

Cells were maintained in culture flasks in complete medium provided with $10 \%$ heat-inactivated FBS and antibiotic cocktail $(100 \mathrm{U} / \mathrm{mL}$ penicillin, $100 \mathrm{~g} / \mathrm{L}$ streptomycin, and $250 \mathrm{~g} / \mathrm{L}$ fungizone). Then, cells were cultured and maintained in a humidified atmosphere at $37^{\circ} \mathrm{C}$ and $5 \% \mathrm{CO}_{2}$.

Cytotoxicity was measured by the 2, 3-bis-(2-methoxy-4-nitro-5sulfophenyl)-2H-tetrazolium-5-carboxanilide, Na2) (XTT) using the colorimetric cell proliferation kit II (F. Hoffmann-La Roche Ltd.). Cells $(100 \mu \mathrm{l})$ were seeded (concentration $1 \times 10^{5}$ cells $/ \mathrm{mL}$ ) into a microtiter plate and incubated for $24 \mathrm{~h}$ to allow the cells to adhere. Compounds were dissolved in DMSO to a stock solution of $20 \mathrm{mg} / \mathrm{ml}$ and then serially diluted from 50 to $1.56 \mu \mathrm{g} / \mathrm{ml}$, added to the plates, and incubated for $72 \mathrm{~h}$. A positive control drug for cytotoxicity, actinomycin D, with concentrations ranging from 0.5 to $0.002 \mu \mathrm{g} / \mathrm{ml}$, negative control of cells with $2 \%$ DMSO was included in the study. After $72 \mathrm{~h}$ incubation, XTT was added to a final concentration of $0.3 \mathrm{mg} / \mathrm{mL}$, and the cells incubated for 2-3 h. The absorbance of the developed color was spectrophotometrically determined using a multiwell plate reader which measured the optical density at $450 \mathrm{~nm}$ with a reference wavelength of $690 \mathrm{~nm}$.

The assay is based on the ability of live cells to reduce the yellow watersoluble XTT into an insoluble formazan product enhancement of the antiherpetic effect of trichosanthin by acyclovir and interferon [7]. Compounds were first screened for their in vitro cytotoxicity at a concentration of $50 \mu \mathrm{g} / \mathrm{ml}$ in HepG2 cells. Active compounds were further tested at concentrations that ranged from 50 to $1.6 \mu \mathrm{g} / \mathrm{ml}$ against HpG2, MDA, and A549 cancer cell lines. A fourth non-cancerous cell line 


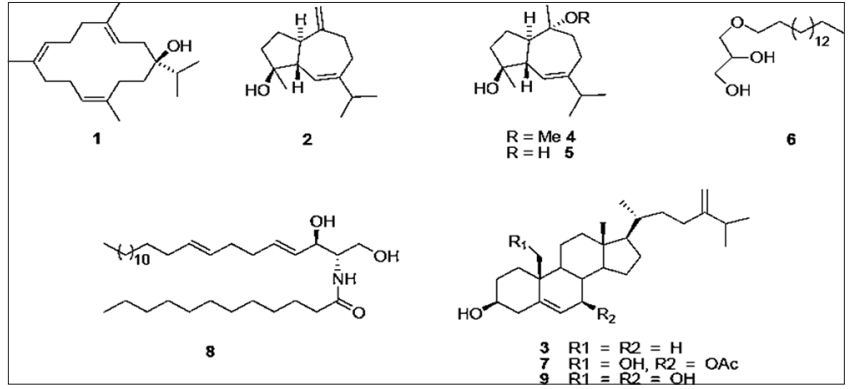

Fig. 1: The chemical structure of Litophyton arboreum isolated compounds [6]

(Vero) was also included for the most active compounds to determine selectivity indices (SI) which represented the overall activity of the compounds. The higher SI values the more selective the compound.

\section{Free radical scavenging activity}

The free radical scavenging activity of compounds was measured by 1,1-diphenyl-2-picryl-hydrazil (DPPH*) using the method of Shimada et al. [8]. All compounds were screened at $100 \mu \mathrm{g} / \mathrm{ml}$ while the most Potentactive compounds (gave more 90\%) were assayed at 25-75 $\mu \mathrm{g} / \mathrm{ml}$. Briefly, $0.1 \mathrm{mM}$ solution of DPPH ${ }^{*}$ in methanol was prepared. Then, $1 \mathrm{ml}$ of this solution was added to $3 \mathrm{ml}$ of compound solution at different concentrations $(25-75 \mu \mathrm{g} / \mathrm{ml})$. The mixture was shaken vigorously and allowed to stand at room temperature for $30 \mathrm{~min}$. Then, the absorbance was measured at $517 \mathrm{~nm}$ in microplate reader. The lower absorbance of the reaction mixture indicated higher free radical scavenging activity [9].

DPPH scavenging effect $(\%)=100-\left[\left(\frac{(\mathrm{A} 0-\mathrm{A} 1)}{\mathrm{A} 0} \times 100\right)\right]$

Where, $\mathrm{A} 0$ was the absorbance of the control reaction and $\mathrm{A} 1$ was the absorbance in the presence of the sample.

\section{Statistical analysis}

Mean IC s0 $_{0}$ is the concentration of compounds which reduces cell growth by $50 \%$ under the experimental conditions and is the average of at least three independent reproducible measurements. The $\mathrm{IC}_{50}$ values were performed using GraphPad Prism (SanDiego, USA). Data were expressed as means \pm standard deviations (SD).

\section{RESULTS}

\section{Cytotoxicity}

The pure compound where an $\mathrm{IC}_{50}$ value is $<10 \mu \mathrm{g} / \mathrm{mL}$ is reported as strongly cytotoxic [10]; hence, the cytotoxicity of the compounds was screened for their cytotoxicity at a concentration of $25 \mu \mathrm{g} / \mathrm{ml}$ in HepG2 cells.

Results showed weak cytotoxic activity for the compound (8) at $25 \mu \mathrm{g} / \mathrm{ml}$ (viability 80\%). Compounds (1) and (5) showed strong toxicity when tested at $25 \mu \mathrm{g} / \mathrm{ml}$, viability of the cells ranged from 30 to $10 \%$. Compounds (2), (7), and (9) showed high toxicity (viability $<10 \%$ ) when tested at $25 \mu \mathrm{g} / \mathrm{ml}$ (Fig. 2).

The most active compounds (2), (7), and (9) were then subjected to further study to determine the $\mathrm{IC}_{50}$ values in HepG2, MDA, and A549 cell lines.

\section{Cytotoxicity $\mathrm{IC}_{50}$ determination}

Table 1 shows the half inhibitory concentration of the active compounds; compound (2) demonstrated a promising cytotoxicity with $\mathrm{IC}_{50} \mathrm{~S}$ of 4.5, 7.02 , and $9.3 \mu \mathrm{g} / \mathrm{ml}$, compound (7) showed strong cytotoxicity with $\mathrm{IC}_{50}$ of $4.5,7.02$, and $9.3 \mu \mathrm{g} / \mathrm{ml}$, and compound (9) revealed a strong cytotoxic activity with $\mathrm{IC}_{50}(6.07,6.3$, and $5.2 \mu \mathrm{g} / \mathrm{ml})$ when compared to cells treated with actinomycin D which showed IC $\mathrm{C}_{50}$ of $17.67,11.88$, and $7.8 \mu \mathrm{g} / \mathrm{ml}$ in HepG2, MDA, and A549 cells, respectively, with high SI.

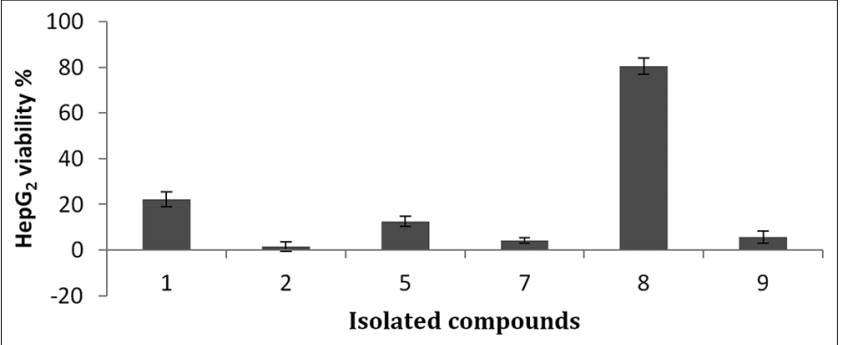

Fig. 2: Viability percentage of HepG2 cells treated with Litophyton arboreum isolated compounds at $25 \mu \mathrm{g} / \mathrm{ml}$. *Values are expressed as mean \pm standard deviation of the three replicates

\section{Free radical scavenging activity}

Compounds were tested at the concentrations ranged from 100 to $500 \mu \mathrm{g} / \mathrm{ml}$; the three compounds exhibited very weak scavenging activities as shown in Table 2 .

\section{DISCUSSION}

Recent studies reported the strong bioactivities of steroids and triterpenoids [11]. In this study, triterpenoids showed also the highest activities among the different tested compounds. Compound (7) from the soft coral nephtheachabroli and compound (9) from the soft coral Litophyton viridis revealed comparable potential cytotoxic effect against various human cancer cell line such as prostate cancer cell line LNCaP with $\mathrm{IC}_{50}(15.5$ and $4.9 \mu \mathrm{g} / \mathrm{mL})$ [7], HT-29 (0.87 and $\left.0.72 \mu \mathrm{g} / \mathrm{mL}\right), \mathrm{KB}(0.38$ and $0.58 \mu \mathrm{g} / \mathrm{mL}$ ), and P-388 (0.42 and $0.24 \mu \mathrm{g} / \mathrm{mL})$, respectively [12]. Compound (7) showed superior activity as compared to that of compound (9). Compound (9) showed immunosuppressive action [13] and when mixed with different tissue homogenates in vivo, it revealed preventive activity against lipid peroxidation [14]. The chemical skeleton of compounds (7) and (9), especially at C-19 in addition to the 5 -ene B ring, which is noticed in an $8 \beta, 9 \alpha$-half-chair conformations, implicated effectively with the activity and the mode of interaction with the cell membranes. Meanwhile, the potency of the activity of such compounds stems from the blockage of the hydroxyl group at C-7 of compound (7) which enhances its lipophilicity [15]. This confirms the role of lipophilicity in the pharmacological activity of the compounds as it increases the ability of the drug penetration for different biological membranes and tissues. This constitutes a lead factor in the interaction of drugs with biological systems [16].

The promising cytotoxic effect has been shown by compound (2) (4.52, 7.02, and $9.23 \mu \mathrm{g} / \mathrm{mL}$ ) in HepG2, MDA, and A549 cancer cell lines, respectively. The compound was previously characterized by being cytostatic (antiproliferative) in HeLa cells [6]. Cytostatic compounds are a good candidate in the production of drugs cocktails as it does not kill cancer cells, but it suppresses its proliferating while another drug is treating it.

According to the National Cancer Institute, it had long been hypothesized that antioxidants can protect against cancer as they scavenge reactive oxygen species that can deteriorate DNA. Despite this fact, a new scope of research confirms that the existence of high levels of antioxidants has been found to prevent a specific free radical damage associated with cancer development, and the antioxidants have been shown to trigger cancer metastasis. In melanoma mouse models, the researcher investigators have demonstrated higher levels of oxidative stress in circulating cancer cells than in cancer cells in primary tumors, and they suggested that the oxidative stress can actually interfere with the development of metastatic tumors. The treatment of these mice with antioxidants suppressed the oxidative stress in the circulating cancer cells and enhanced their capability to metastasize [17]. Another study in mouse models of human lung cancer suggested that supplementing the antioxidants $\mathrm{N}$-acetyl cysteine or Vitamin $\mathrm{E}$ in the diet of mice substantially increased the size and stage of the tumors [18]. The weak free radical scavenging activities of the three most cytotoxic compounds 
Table 1: The half inhibitory concentration of the active compounds in HepG2, MDA, A549, and Vero cell lines as well as their SI

\begin{tabular}{|c|c|c|c|c|c|c|c|c|}
\hline \multirow[t]{2}{*}{ Cell lines } & \multicolumn{2}{|l|}{ Compound 2} & \multicolumn{2}{|l|}{ Compound 7} & \multicolumn{2}{|l|}{ Compound 9} & \multicolumn{2}{|l|}{ Actinomycin D } \\
\hline & $\mathrm{IC}_{50} \pm \mathrm{SD}(\mu \mathrm{g} / \mathrm{ml})$ & SI & $\mathrm{IC}_{50} \pm \mathrm{SD}(\mu \mathrm{g} / \mathrm{ml})$ & SI & $\mathrm{IC}_{50} \pm \mathrm{SD}(\mu \mathrm{g} / \mathrm{ml})$ & SI & $\mathrm{IC}_{50} \pm \mathrm{SD}(\mu \mathrm{g} / \mathrm{ml})$ & SI \\
\hline HepG2 cells & $4.52 \pm 0.1113$ & 2.93 & $6.07 \pm 0.09286$ & 1.19 & $8.5 \pm 0.1898$ & 1.4 & $17.67 \pm 0.102$ & 0.43 \\
\hline MDA cells & $7.02 \pm 0.08407$ & 1.88 & $6.3 \pm 0.1909$ & 1.14 & $5.5 \pm 0.2104$ & 2.2 & $11.88 \pm 0.3 .4$ & 0.63 \\
\hline A549 cells & $9.23 \pm 0.1062$ & 1.43 & $5.2 \pm 0.1465$ & 1.38 & $9.3 \pm 0.9093$ & 1.3 & $15.62 \pm 0.130$ & 0.48 \\
\hline Vero cells & $13.23 \pm 0.1062$ & & $7.2 \pm 0.1465$ & & $12.3 \pm 0.9093$ & & $7.52 \pm 0.201$ & \\
\hline
\end{tabular}

*Values are expressed as mean \pm standard deviation of the three replicates. SI: Selectivity indices

Table 2: The scavenging percentage of the tested compounds compared to the positive controls Vitamin $\mathrm{C}$ and BHA

\begin{tabular}{ll}
\hline Compound & Scavenging (\%) \\
\hline Compound 2 & 10.8 \\
Compound 7 & 22.4 \\
Compound 9 & 14.5 \\
\hline${ }^{*} T h e \mathrm{IC}_{50}$ value of the positive control, Vitamin C, was measured as \\
$12 \pm 3.5 \mu \mathrm{g} / \mathrm{ml}^{*}$ The IC $_{50}$ of the positive control, BHA, was measured as $53 \pm 3.1$ \\
$\mu \mathrm{g} / \mathrm{ml}$. BHA: Butylated hydroxyanisole
\end{tabular}

tested in this study can then be an advantage for the record of drug design, especially for lung cancer.

Determination of antioxidant activity by one method cannot identify all possible mechanisms. Therefore, different free radical scavenging methods should be considered in future research [19].

\section{CONCLUSION}

The current approach provides important insights into marine steroids which are considered as the most active chemical class for the discovery of bioactive anticancer drugs. In this work, we report for the $1^{\text {st }}$ time, the cytotoxic effect of 7 $\beta$-acetoxy-24-methylcholesta-5-24 (28)-diene3,19-diol (7) and 24-methylcholesta-5,24(28)-diene-3 $\beta, 7 \beta, 19-$ triol (9) on the major cancer types (liver, lung, and breast cancer cells).

Polyhydroxylated sterols, especially those derived from the marine organism, showed a potent cytotoxic impact on cancer cell lines. This sheds light on the importance of this chemical skeleton in developing active anticancer drugs from marine organisms. The mechanism of cytotoxic activity with the weak antioxidant activity of the compounds has more to be explained in further studies, but it can be considered as an advantage as it will not interfere with the metabolic mechanism of the cells. The polyhydroxysterols skeleton of our compounds is similar to the human sterols, so it can be accounted as promising lead compounds for the development of new, safe, and effective chemotherapy.

\section{AUTHORS' CONTRIBUTION}

Dr. Mona Ellithey participated actively in invention of the scientific idea, arranging and preparing the experimental step, preparing the compounds, conducting the necessary cell culture assays, analyzing the data, and writing the paper. Prof Hanaa Hamdy participated actively in invention of the scientific idea, conducting the necessary biochemical analyses, revising the paper critically, editing and approving the final version, and submission of the manuscript to the journal.

\section{CONFLICTS OF INTEREST}

The authors declare that there are no conflicts of interest.

\section{REFERENCES}

1. Sarma NS, Krishna MS, Pasha SG, Rao TS, Venkateswarlu Y, Parameswaran PS. Marine metabolites: The sterols of soft coral. Chem Rev 2009;109:2803-28.

2. Fang HY, Hsu CH, Chao CH, Wen ZH, Wu YC, Dai CF, et al. Cytotoxic and anti-inflammatory metabolites from the soft coral Scleronephthya gracillimum. Mar Drugs 2013;11:1853-65.

3. Zhang J, LiLC, Wang KL, LiaoXJ, DengZ, XuSH. Pentacyclichemiacetal sterol with antifouling and cytotoxic activities from the soft coral Nephthea sp. Bioorg Med Chem Lett 2013;23:1079-82.

4. Tsai TC, Huang YT, Chou SK, Shih MC, Chiang CY, Su JH. Cytotoxic oxygenated steroids from the soft coral Nephthea erecta. Chem Pharm Bull (Tokyo) 2016;64:1519-22.

5. Huang CY, Chang CW, Tseng YJ, Lee J, Sung PJ, Su JH, et al. Bioactive steroids from the formosan soft coral Umbellulifera petasites. Mar Drugs 2016;14:180.

6. Ellithey MS, Lall N, Hussein AA, Meyer D. Cytotoxic, cytostatic and HIV-1 PR inhibitory activities of the soft coral Litophyton arboretum. Mar Drugs 2013;11:4917-36.

7. Zhang W, Liu WK, Che CT. Polyhydroxylated steroids and other constituents of the soft coral Nephthea chabroli. Chem Pharm Bull 2003;51:1009-11.

8. Shimada K, Fujikawa K, Yahara K, Nakamura T. Antioxidative properties of xanthone on the auto oxidation of soybean in cylcodextrin emulsion. J Agric Food Chem 1992;40:945-94.

9. Biswas M, Haldar PK, Ghosh AK. Antioxidant and free-radicalscavenging effects of fruits of Dregeavolubilis. J Nat Sci Biol Med 2010;1:29-34.

10. Prayong P, Barusrux S, Weerapreeyakul N. Cytotoxic activity screening of some indigenous Thai plants. Fitoterapia 2008;79:598-601.

11. Warad VB, Habbu P, Shastri R. Antimicrobial activity of Callyspongia diffusa (marine sponge) associated endophyic bacterial L strains. Int J Pharm Pharm Sci 2017;90-6.

12. Duh CY, Wang SK, Chu MJ, Sheu JH. Cytotoxic sterols from the soft coral Nephthea erecta. J Nat Prod 1998;61:1022-4.

13. El Sayed KA, Bartyzel P, Shen X, Perry TL, Zjawiony JK, Hamann MT. Marine natural products as antituberculosis agents. Tetrahedron 2000;56:949-53.

14. Hu Q, Zhao J, Xu S. Effects of 3 $\beta, 7 \beta, 19$-trihydroxy-24-methylene- $\Delta 5$ cholesten on the immune system of mice. Redai Haiyang 1998;17:75-9.

15. Xu S, Zhao J, Hu Q, Wang Z, Li R. Study on antioxidation of 24-methylene-3 $\beta, 7 \beta, 19$-trihydroxy-5-cholestene. Chin Pharmacol Bull 1997;13:81-4.

16. Emil P, Daniela C, Michael E, Clay C, Jean D. Lipophilicity parameters and biological activity in a series of compounds with potential cardiovascular applications. Croat Chem Acta 2004;77:1-2.

17. Elena P, Michalis A, Malea M, Hu Z, Sara E, Zhiyu Z, et al. Oxidative stress inhibits distant metastasis by human melanoma cells. Nature 2015;7577:186-91.

18. Volkan I, Mohamed X, Erik L, Jonas A, Per L, Martin O. Antioxidants accelerate lung cancer progression in mice. Sci Transl Med 2014;221:221.

19. Nagaseshu P, Gayatridevi V, Kumar BA, Kumari S, Mohan GM, Malla RR. Antioxidant and antiproliferative potentials of marine Actinomycetes. Int J Pharm Pharm Sci 2016;8:277-84. 